\title{
Competitiveness and technological innovation, fundamental theoretical elements for the internationalization of the Mexican Wine Industry
}

\section{La competitividad y la innovación tecnológica, elementos teóricos fundamentales para la internacionalización de la Industria Vitivinícola Mexicana}

\author{
MOLINA-MARTÍNEZ, Rubén† \& BALTAZAR-RAMOS, Vianey \\ Universidad Michoacana de San Nicolás de Hidalgo, Mexico.
}

ID $1^{\text {st }}$ Author: Rubén, Molina-Martínez / ORC ID: 0000-0002-9840-6441, Research ID Thomson: K-7424-2018, CVU CONACYT ID: 14701

ID $1^{\text {st }}$ Co-author: Vianey, Baltazar-Ramos / ORC ID: 0000-0002-1500-8828, CVU CONACYT ID: 889013

DOI: $10.35429 / \mathrm{JMPC} .2021 .19 .7 .7 .23$

Received: January 15; Accepted: June 30, 2020

\begin{abstract}
The objective of this research is to examine some of the theories of competitiveness and technological innovation that allow wine companies to develop internationalization strategies in the current framework of economic globalization. The implementation of these strategic decisions not only requires research efforts, but it also requires the participation of the collaborative network of the segments related to productive infrastructures. In Mexico, the wine sector presents a growth perspective due in part to the differentiation and expansion of the markets, but it also presents challenges of product offer, financing for the growth of the company and government policies such as the reduction of taxes that would allow the sector increase competitiveness. The methodology of this study is of an exploratory descriptive nature, since it aims to serve as theoretical support so that companies have the information that allows them to design the necessary internationalization strategies to have a dominant market share presence at the national and international level. The contribution of the qualitative analysis of this work lies in the dissemination of information on the subject, the debate of the concepts and the development of these competences; both at the business and academic level.
\end{abstract}

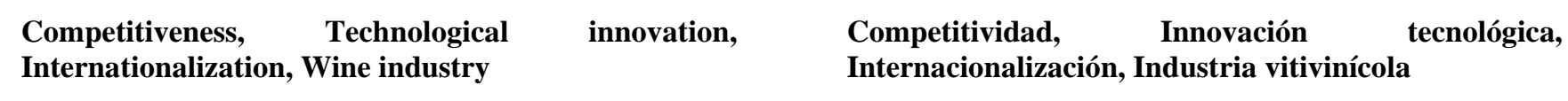

Citation: MOLINA-MARTÍNEZ, Rubén \& BALTAZAR-RAMOS, Vianey. Competitiveness and technological innovation, fundamental theoretical elements for the internationalization of the Mexican Wine Industry. Journal of Microfinance Planning and Control. 2021. 7-19:7-23.

\begin{abstract}
Resumen
El objetivo de esta investigación es examinar algunas de las teorías de competitividad e innovación tecnológica que permiten a las empresas vitivinícolas desarrollar estrategias de internacionalización en el marco actual de la globalización económica. La implementación de estas decisiones estratégicas no sólo requiere de los esfuerzos de investigación, también requiere de la participación de la red de colaboración de los segmentos relacionados con las infraestructuras productivas. En México el sector vinícola presenta una perspectiva de crecimiento debido en parte a la diferenciación y ampliación de mercados, pero también exhibe retos de abastecimiento de productos, financiamiento para el crecimiento de la empresa y políticas gubernamentales como la disminución de impuestos que le permitiría al sector aumentar la competitividad. La metodología de este estudio es de carácter exploratorio descriptivo, ya que pretende servir de sustento teórico para que las empresas cuenten con la información que les permita diseñar las estrategias de internacionalización necesarias para tener una presencia de participación de mercado dominante a nivel nacional e internacional. La contribución del análisis cualitativo de este trabajo radica en la difusión de la información del tema, el debate de los conceptos y desarrollo de estas competencias; tanto a nivel empresarial como académico.
\end{abstract}

Competitividad, Innovación tecnológica, Internacionalización, Industria vitivinícola 


\section{Introduction}

The international market for vineyards, wine and wine products is a productive system that has had a worldwide expansion since the mid-1990s. Globalization, competitiveness, and technological innovation of wine exporting companies; as well as the increase in demand from the new consuming countries have contributed to making this industry one of the most productive in recent decades.

The wine industry has been around the world since the Bronze Age when the first grapes (Vitis vinifera sylvestris) began to be cultivated and fermented. Mexico has a long wine-growing history and the oldest vineyards in America. In 1524 the Spanish brought with them the habit of drinking wine, but it was in 1594 when the Casa Madero company was founded in Valley of Parra's Coahuila; the first farm to produce wine and brandy (Casa Madero, 2020).

The vine plants used to make Mexican wine come from France, Italy, and the United States. The vine has an average life of 50 years, the fullness stage for wine production ranges from 10 to 30, and they can reach up to 100 years of life. In Mexico, more than 29,000 hectares are destined to produce grapes: table wine, juices and concentrates, grapes for brandy, raisins, and table grapes. The cultivation of the vine for wine, along with table grapes for human consumption, represents the second largest employment force in the fruit and vegetable sector in Mexico with more than 500 thousand agricultural laborers. In total, 6,747 hectares are dedicated to the production of wine, of which $70 \%$ comes from the state of Baja California (Consejo Mexicano Vitivinícola, 2019).

The world production of wine in the last fifteen years has remained between 25 thousand and 30 thousand million liters. The main wine producers in the last 6 years are Italy, France, and Spain; placing Argentina, a Latin American country, in sixth place according to the data of the World Wine Organization for the year 2019. The structure of the wine sector worldwide has changed significantly in the last four decades, derived from the increase in the market consumer, best production practices, innovation in processes and more efficient communication channels (Fernández, 2013, p. 22).
The industry that traditionally evoked artisanal processes currently includes high technology and sustainable products in its processes. This has favored emerging countries commonly known as producers of the "new world" (United States, China, Australia, Argentina, Mexico, among others; which before 1980 were not important wine producers worldwide) are now among the leading countries in exports; almost on a par with European or "old continent" suppliers (France, Italy, Spain, among others), which continue to dominate the world wine market (Fernández, 2013, p. 22).

In Mexico there are 14 states that produce around 2.4 million cases of wine per year. The main regions in which 230 wineries and trading companies are distributed are: Baja California, Coahuila, Zacatecas, Querétaro, Sonora, Durango, Aguascalientes, Chihuahua, San Luis Potosí, Guanajuato, Nuevo León, Jalisco, Puebla, and the State of Mexico. The surface of the Mexican territory destined to the cultivation of the vine for 2018 was 6,747 hectares, of which Baja California stands out in first place with $67 \%$, Coahuila in second place with $8.5 \%$, Queretaro in third place with $4.0 \%$ and Guanajuato with the $2.3 \%$ (SIAP, 2018). In the country, the internal demand is approximately 9 million boxes, according to figures from the Mexican Wine Council.

The consumption of grape-based wine doubled in five years since the average per capita per Mexican in 2012 was 450 milliliters while in 2018 it was 960 milliliters. In such a way that by 2019126 million liters were ingested, that is, approximately $0.5 \%$ worldwide (CMV, 2019). The consumption of wine in Mexico is lower compared to other countries since it is considered as an alcoholic beverage and not as part of a food culture or a product that benefits health due to its nutritional value. This has an effect mainly on the final price that the consumer pays for each bottle of wine, since in the country a bottle of wine with an alcoholic content of up to 14 degrees is reduced in the cost of sale by a $42.5 \%$ tax. (16\% VAT and $26.5 \%$ IEPS). 
The wine market in Mexico is characterized by a strong competition from foreign wine products, which is considered a disadvantage for domestic producers, since they lack subsidiary support and government tariff protection. Even though the International Wine Organization OIV promotes regulations to minimize barriers to trade, reduce taxes and sustainable production; it is necessary for the country to consider this activity as a promoter of the agri-food sector; since the industry in addition to having an important participation in the market also promotes tourism, foreign investment, sustainability, and development of communities.

Likewise, Mexican wine has consolidated its growth and participation in the national and international market, by placing for the first time on the list of the 10 countries with the most awarded wines in the 2019 Brussels World Contest. In the same way that the Valle de Guadalupe region by winning the "World Revelation Red Wine" award in a competition of 5,393 bottles of red wines from around the world (Forbes Mexico, 2019). The Mexican Wine Council (CMV) oversees promoting the development of vine cultivation, the industrialization of the grape, the commercialization; as well as the promotion of the products obtained from it. Due to their work, the country has a Collective Brand of Mexican Wine, distinctive of quality and origin at an international level. This is how through innovative proposals, international recognition and quality certifications, exports in the country increase and diversify every year to markets in the United States, Europe, and Asia.

In this paper some theories of competitiveness and technological innovation are mentioned, which contribute to the internationalization of the wine industry, as well as the use of digital platforms on the Internet for the promotion and financing of their projects.

\section{Literary review}

\section{Theories of Competitiveness}

Competitiveness is the ability of economic agents to remain selling goods or services in a market, as well as to export products that compete in an international market (Sepúlveda, 2010, p. 187).
The evolution of the term competitiveness through the years begins and develops with the theories of the most influential economists of the 20th century, through Adam Smith, John Keynes, and Joseph Schumpeter. However, nowadays there is not a sufficient theoretical perspective to define this term; since it considers factors and conditions both qualitative and quantitative in dimensions at the local, regional, national, and international levels. It is important to mention that the difference between the concept of competition and competitiveness is that the former is the result of the effort of individuals or companies to gain the preference of a market by satisfying their needs with a product or service and having an exchange of this. While the second seeks greater market share including product differentiation, specialization and innovation, better service and a priori vision of consumer wants or needs (Porter, 1985, pp. 51-56).

The Classical Economic Theory is one of the first that refers to competitiveness, in which Adam Smith and David Ricardo demonstrated the benefits of capital investment, specialization in products where there was a comparative advantage and free trade as an advantage for productivity, including technological production. Neoclassical Theory supported the model that postulated that comparative advantage resided in the abundance generated by independent factors of production, including labor and capital; however, under conditions of perfect competition, competitiveness was not sustainable in the long term (Porter, 1990, p. 73).

In the nineties, it was thought that the economic wealth of a country was determined by its competitiveness in world markets, Jacques Delors claimed that countries compete in these markets as companies do. However, as we will see later, this international competition is more a rivalry for status and power than what can really affect or benefit one country to another with its domestic productivity. Paul Krugman (1994, p. 32). believed that competitiveness should only apply to corporations, which were intended to compete in the marketplace. It is these companies and their performance that define their survival or failure; on the contrary of a market economy or a country that cannot fail. 
Poor planning affects the achievement of its primary objective of improving the population's standard of living, which is causally related to the productivity or profitability rates of companies and not to their competitiveness in world trade.

For the author, thinking about competitiveness issues in the long run brought more disadvantages than advantages, since it led to bad political and economic practices. He even thought that unemployment benefits caused unemployment; not only because the term competitiveness is a nonsense word that can be used in public policy as a melodious word to attract attention and win supporters. Also, because making decisions without considering the real figures of economic factors and without considering their results; it can lead to indebtedness and crisis on the part of the States; due to useless expenses, fraud, or job losses due to the excessive use of new technology in this idea of competing with the "leading" countries, which would lead to social problems such as lack of purchasing power, quality of life, famine and problems of health (Krugman,1994, pp. 35-44).

Competitive intelligence (CI) is a structured, legal, and ethical process, which is planned and designed to obtain, analyze, interpret, and disseminate information about the industry, the environment, and its current and potential competitors; as well as the threats and opportunities that concern it. All of this for the strategic decision-making of those responsible for an organization or company in search of a competitive advantage and permanence in the market (Porter, 1999, p. 163).

The importance of this concept that emerged in the eighties as a need to adapt to technological development and globalization, reached its maturity with the degree of complexity in the field of products and services. The increasingly demanding standards, the greater diversification, as well as the reduction of waiting time to satisfy the needs throughout the production chain; have forced companies to consider variables and information databases that allow them to anticipate potential consumer behavior (Rivera, Arellano, \& Molero, 2013, pp. 353-361).
In this sense, the company must identify the specific parts of the environment that can provide timely information on trends so that management can foresee changes, especially in scientific and technical innovation. The GTI Lab divides the CI into four categories: Business intelligence that includes those involved with the company's sales network such as customers, suppliers, producers, buyers, and distributors. The intelligence of competitors including policies, substitute products, and business developments. Technical and Technological intelligence such as processes, factories, standards, and patents. And the intelligence of the social structure such as policies and financial markets (BAI, n.d, p.14).

Competitive surveillance arises as a need to observe and analyze the environment of the company to respond to changes. This studies data regarding customers and suppliers, competitors, available technologies; and the environment in areas such as sociology, politics, and the environment (Martinet and Marti, 1995, p. 106).

Knowledge management is a discipline that allows internal and external transfer of knowledge and experiences from one person or groups of people to others, to transmit information and skills that will generate sustainable competitive advantages to the organization. This discipline or process began to gain relevance with technological development and the global opening of markets, allowing the development of tools for the treatment of information and data in an expeditious manner for making strategic decisions (Godet, 1995, pp. 329-355).

This field includes the concept of Business Intelligence that refers to a set of strategic decisions in tactical aspects of the organization, based on the analysis of quantitative data of internal information on the company's resources; in other words, it focuses on the operational part. The use of this concept through technological tools, implementation of information systems and competitive personnel to interpret the results can help the company to achieve a systemic process of competitive intelligence (Kahaner, 1997, pp. 20-35). 


\section{Theories of Technological Innovation}

The Heckscher-Ohlin theory analyzes the effects of factor endowments in international trade at the beginning of the 20th century, formulated by the Swedish economist Bertil Ohlin in 1933 who modified an initial theorem of his teacher Eli Heckscher formulated in 1919. This theory it was based in part on David Ricardo's theory of comparative advantage, which stated that countries specialize in the export of goods whose production is intensive in the factor in which the country is abundant, while they import those goods whose production is intensive in the relatively scarce factor in the country (Fernández \& Subirá, 2006, p. 85). However, the HeckscherOhlin theory explained that the advantage lies in the factors of production (land, labor, and capital), and of technology that each country possesses, and the proportion in which they are used to produce goods. In this way, the countries will export the goods that are produced with the most abundant factors and import those produced with scarce factors. Which mainly benefits the costs of each factor. This model suggests that international trade should be determined by differences in factor endowments, rather than by disparities between productivity, since in the end trade tends to equalize the price of production factors, benefiting all participants (Appleyard \& Field, 2014, p. 137).

The criticism of this model is to consider that the technology is the same in all countries, that prices are equal between countries without considering tariffs, taxes, etc., and that all countries have the same factor endowment. Based on the Heckscher-Ohlin theory, the 1953 Nobel Prize winner Wassily Leontief posited his paradox which said that the most technologically advanced countries had a larger, more skilled, and entrepreneurial labor supply. As a result, they invested more capital in training to generate a competitive advantage by being more productive than the rest of the world (Brecher \& Choudhri, 1993, pp. 272-285). Leontief's study is based on the empirical evidence that he generated as part of the Systematic Analysis of the Structure of the United States Economy, which assumed that with an abundance of capital he must be an exporter of capital goods; the reality was that their exports were higher in noncapital labor-intensive products (Leamer, 1980, pp.495-496).
Michael E. Porter in 1980 introduces concepts included in the industrial organization models within business strategy, suggesting an analysis of the environment (the industry) to create and sustain a competitive advantage. In 1985 he elaborated a tool to analyze the sources of competitive advantage of companies and their relevant activities to understand the behavior of costs and the sources of differentiation. But it is until 1990 that this author carried out an investigation to determine why some countries prosper and others fail in each sector in international competition. It establishes that there are four factors that promote or hinder competitive advantage, these factors are called "diamond" and establish a system of reciprocal reinforcement in the economic sectors where companies participate, considering that there are also other fortuitous factors such as innovations, and the participation of the governments of each country that with their policies, stimulate and hinder the national advantage (Porter, 1990, p. 78). The four factors of the Porter diamond are:

1. Factor endowment. Analyze the factors of production of the Heckscher-Ohin theory. Based on this, it detects two hierarchies in the factors that are: the basic and the advanced. In the former, it considers the essential factors that a company needs to carry out its economic activity, such as resources, geographical location, environmental, demographic and market factors. In the advanced ones, it considers the most important to maintain a competitive advantage due to investments: job specialization, communications infrastructure, information, and technological capabilities.

2. Demand conditions. Internal demand plays an important role in competitive advantage, since companies are pressured to innovate and increase quality by their consumers; this in turn causes the attributes of national products to be better.

3. Related and support sectors. Investments in advanced factors of production in these sectors allow the national advantage to increase. The prosperous and successful companies are grouped into related categories and pass on knowledge among themselves that benefits the entire sector, allowing them to achieve an international competitive position. 
4. Strategy, structure, and rivalry of companies. Countries have different administrative ideologies that can stimulate the competitiveness of a country. The constant internal rivalry of companies forces them to innovate, modernize and reduce costs to compete internationally (Porter, 1990, cited in Hill, 2015, p. 179).

Sherman Gee (1981) defines the concept of innovation "as the process in which, from an idea, invention or recognition of a need, a useful product, technique or service is developed until it is commercially accepted" (Gee, 1981, cited in Sazali \& Raduan, 2011).

Joseph Schumpeter (1934) develops the concept of innovation as an essential process of economic change that includes invention, diffusion, and imitation. During the first half of the 20th century, he proposed a theory of economic development on the subject, taking ideas from theories such as those of Karl Marx, Max Weber, and Karl Menger. This proposal includes two concepts: innovation as a cause of development and the innovative entrepreneur as a promoter of innovation processes. For Schumpeter, the production process is formed by a combination of material forces (labor, land, and capital) that cause a gradual and slow change in the growth of the economic system; and by immaterial forces (technical facts and social organization) that provoke social technological changes, which in turn exert a more dynamic and decisive change in economic development. Likewise, the innovative entrepreneur is prepared and motivated to make structural changes assuming the risk that a new idea entails in the market, because innovation is the most important force of economic growth; since it contemplates the process of "creative destruction" which restructures the company from within, destroying the old to make way for the new (Schumpeter, 1942, p.83).

For Montoya (2004) what is important are radical innovations, capable of causing revolutionary changes in the capitalist system, society, and the economy. These radical innovations include:

The introduction of new consumer goods on the market, with which consumers are not familiar.
- The emergence of a new method of production and transportation, which is generally the product of a scientific or technological discovery.

The achievement of the opening of a new market, existing or non-existent in another country.

- The generation of a new supply source for raw materials or semi-finished products.

- The implementation in the structure of the organization or management process (Montoya, 2004, p. 211).

Theory of innovative environment or the "milieux innovateurs". This theory arises in the mid-eighties with the work of the French economist Philippe Aydalot (1986), later developed by the European Research Group on the best innovators dedicated to the development of production systems and technological innovation, Le Groupe de Recherche Européen sur les Milieux Innovateurs (GREMI). This explanatory theory of regional development where the capacity for innovation and transmission of knowledge depends on variables and endogenous factors of the territories themselves. The role of intangible resources, the closeness of relational assets (immediate reaction capacity), and the relevance of cooperation and learning in the dynamics of regeneration and restructuring of activities to renew innovation processes are highlighted (Kirat \& Lung, 1999; Fisher, 2001).

In this theory of the innovative environment, by environment refers to the capacity that a certain territorial area must capitalize on the geographical proximity of the actors in the form of skills and behaviors oriented to the production, transmission and accumulation of knowledge related to productive activities. Either by the combination of productive inputs of the companies, via outsourcing, organic internationalization, or integration (Quevit, 1991; Furió, 1996a; Melia, 1998). 
This environment has four properties that encourage economic development and exchange; the existence of a group of autonomous actors in their strategic decisions, the provision of material and institutional elements, a logic of interaction between the actors that capitalizes on existing resources, and a learning dynamic or the actors' ability to seek solutions to new problems derived from changes in the national and international environment (Peña, 2006, p. 446). According to the above, the environment is innovative when two requirements are met:

a) An opening to the outside to assimilate the specific resources it needs.

b) The ability to create "innovation networks" that develop the creative capacity of the environment.

Innovative environments revolve around three important areas: technological dynamics, territorial transformation, and organizational changes. Technological dynamics include not only the development of patents or investment in research; also, the development of new techniques and products to maintain the competitiveness and differentiation of the firms. Territorial transformation shows the territory as an organization that generates resources (knowledge, skills, capital) and actors (companies, innovators, support institutions). Within this concept, the territory is considered as an organization that links companies, institutions, and the local population.

The organizational changes contemplate the mechanisms of a community that allow or prevent the coordination of actors, describe the local rules of competition and cooperation to establish functional complementarities and division of labor that are organized in local networks and production systems (Crevoisier, 2001, pp. 156-158).

Companies "Born Global or International New Ventures", have a presence in many countries of the world, thanks to commercial globalization that has favored the formation of networks (personal, commercial, and institutional) and strategic alliances that facilitate their insertion into international markets.
In addition to the use of information technologies and reduction of transport costs. Only those belonging to services and high technology are classified as Born Global; however, this trend today is open to a wide range of industries (Plá \& Escribá, 2006, p. 256).

These companies follow a different model from the traditional "Uppsala model" where a series of stages is contemplated in which the company gradually goes international to enter global markets; these "small" companies do so from the moment of their birth or establishment, in a short period that according to some authors varies from 2 to 6 years. Most of them make intensive use and application of knowledge and the process of imitating technologies to produce goods and services, commonly hiring assets or resources that, due to their size, could be limited, such as financial, human, property, plant, or equipment. Due to this, they often focus on a small segment or market niche, to later expand the company (Plá \& León, 2004, cited in Brenes \& León, 2008, p. 14).

Considering some strengths of these companies we can mention that they have flexible organizational structures, focused on making strategic decisions by entrepreneurs or management groups with a proactive and visionary attitude; that they are not only academically trained to run these companies; they also have experience acquired in international markets where they have developed skills and abilities to manage risks and challenges. Their main source of information about clients, institutions and opportunities in other markets are, on the one hand, domestic and international networks that give them a competitive advantage worldwide; and, on the other hand, the governance or joint administration structures with other companies, called "hybrid structures", which provide them with information through distribution agreements, licenses, franchises, or joint ventures; to name a few. To enter international markets, these companies use exports, licenses, and direct investments. As for customers, they are information and communication technologies, which allow them to be in constant and expeditious communication about needs, tastes, and preferences (Araya, 2009, p. 23). 
For a company to be able to sustain itself in the market, four necessary elements are indicated according to Oviatt and McDougall (1994): the ability to internalize a transaction; use of hybrid or alternative resource structures, identify an opportunity or advantage in the foreign market, as well as possess and take advantage of the resources that are unique to a particular company (p. 53). At the international level, economic policies and fiscal measures are needed that favor the conditions and infrastructures necessary for the development of exports; as well as promoting the formation of business networks for the integration of companies at a regional and sectoral level, through cooperation agreements or clusters. And of course, encourage training programs that train international entrepreneurs with knowledge, skills, and abilities (Brenes \& León, 2008, p.16).

Globalization and technological development have shortened distances and time, in the same way that it has increased the means to communicate and interact. In labor internationalization, one of the important aspects to consider is the culture, that is, values, customs, beliefs, knowledge, and ways of life of a person or a group. According to Drew Martin (2003), culture influences negotiations in four ways: 1) conditioning the perception of reality; 2) blocking all information inconsistent with conceptions rooted in our culture; 3 ) assigning a meaning to the words and actions of the other party, and 4) leading the ethnocentric observer to an incorrect attribution of motives. For Roger Fisher and William Ury (1985), negotiation should be a more dynamic process where negotiators, interests, solutions, and criteria must be considered.

The $21^{\text {st }}$ century negotiation model makes it more evident to establish a collective bargaining agreement that meets the needs of the company, the workers, and their representatives. It requires an "abundance mentality" with the goal of win to win from all parties. Negotiation seen as a process must consider aspects such as the diagnosis of conflict, the involvement of the organization, and the conciliation of the different organizational agents. An organizational consultant who plays the role of mediator and neutral party is recommended.
In this sense, the Firm Theory called Resource-Based Theory explains the important relationships between organizational phenomena, the nature and the essence of the firm that be one. They are reduced to the diagnosis, configuration and combination of knowledge assets and organizational capabilities to allow the directors of these organizations to capture value (profit) from both the creative and routine operations of the firm (Pitelis \& Teece, 2009, p. 27).

Key top management or strategic decisions involve not only issues of authority and employment, but also issues of finances, resource allocation, and choice of business model. An acceptable theory should also help illuminate how managers or entrepreneurs decide:

1. If they invest in the development of new products or processes.

\section{Activities to outsource.}

3. How to set the price of the products.

4. The value proposition to the customer.

In strategic management, the concept of dynamic capabilities is a term that reflects the ability to renew and adapt to the changing environment (Pavlou \& Sawy, 2011, pp. 242, 261) and mainly includes three concepts: administrative capabilities related to the integration and coordination of resources and activities; organizational capabilities, which are related to improving the performance and productivity of its assets to generate a sustainable competitive advantage; and strategic capacities, which are related as their name implies, with the implementation and evaluation of the impact of the strategies. Jay B. Barney (1991) stated that a firm has a sustained competitive advantage when it implements a strategy that generates value, and that it is not being implemented simultaneously by its current and potential competition, being unable to duplicate the benefits of this strategy (Barney, 1991, p. 102). 
Regarding dynamic administrative capabilities and managers, it is necessary for managers to reconfigure these capabilities in response to changing environmental conditions, creating, and combining various types of organizational capabilities. Trying to identify new trends and opportunities, to integrate new ideas and knowledge to existing capabilities. Managers in a business context perform the critical work of a continuous orchestration of the assets of an organization to promote productive changes, with a harmonious and synchronized work to achieve high performance (Teece, 2007, p. 1320). Their personal experience influences strategic decisions regarding the search for opportunities in the environment to take advantage of them and configure resources for their efficient use; as well as the management of threats that it faces in a dynamic, complex, and uncertain environment. For a company to be competitive, it is necessary to establish a strategic model that allows it to achieve and maintain a competitive advantage in the market through the proper use of its resources, capabilities, and skills; considering both the endogenous and exogenous factors that concern it. Within this model, the diagnosis, analysis, exploitation and renewal of resources and capacities must be considered to obtain the best profitability for the firm or company (Collís, 2019, pp. 4-11). This model includes at least five stages described below:

1. The identification of tangible and intangible resources, which defined by Birger Wernefelt include the inputs in the firm's operations, such as plant and equipment; to outputs such as staff skills and competencies, including knowledge and intellectual capital. Assess the strengths and weaknesses that competitors offer, as well as identify opportunities for the use of resources in certain sectors or in markets where they are potentialized (Wernerfelt, 1984, p. 172).

2. Identify the capabilities of the firm, its input resources, and the complexity of each. Robert Grant defines capabilities as an ability to perform a task or activity with patterns of coordination between people and resources. This includes the organizational habits that are born from experience and that form routines and patterns of interaction in concrete and repetitive situations (Grant, 1991, p. 122).
3. Assess or estimate the income potential generated from resources and capacities according to their potential to generate skills that ensure the sustainability of the competitive advantage, as well as the appropriation of its profits. For this, not only investments must be made, but also be attentive to the behavior of the market, starting from the generation of value and what the company does best, which makes it unique and unrepeatable according to Prahalad and Hamel (1995).

4. Select a strategy that best exploits the resources and capabilities of the firm contemplating the opportunities to establish it. Considering the internal resources and capacities provided by the management and that are the primary source of benefits or profitability for the firm. This implies a permanent state of vigilance to invest in developing other markets or looking for new ones.

5. This permanent surveillance system allows identifying the resource gaps that need to be filled, as well as investing in the replacement, improvement and increase of the firm's base resources; as well as the creation of new resources and capacities (Collís, 2019, pp. 4-11).

Finally, it should be noted that any strategic model must start from the organizational mission, considering the resources that are available and not only external information to know if the company has enough elements to fulfil the expectations and demands of the environment.

The information technology revolution has had an impact on the organizational forms of work both in the decentralization of activities in a physical place and in the generation of 'ad hoc' jobs for the new merchandising (web operations, marketing, and shipping). However, for traditional companies it is still more financially expensive to modify their structure due to sunk costs in infrastructure. 
On the contrary, companies that were born online and that can contract information technology infrastructures and software, reduce their initial investments through the variability of transaction costs, market prices and aggregate profitability, and increase entry barriers with investments in marketing (image), to stay in the market and remain leaders, like eBay or Amazon companies. Despite this, the entry of the internet to the market has redefined the way of competing by making the structures more transparent and accessible to products and services; thus, improving the value chain, the organizational forms, and the regulations in the setting of prices. Resulting in a global digital economy of exchange and consumption (Cassiman \& Sieber, 2001, p. 22).

Digital technologies have influenced economic growth, social inclusion, government programs, and environmental policies. The information in practically any activity is handled by an electronic medium or device that allows quick and expeditious access. According to data from the Telecommunications Union (ITU) for 2015 , it was estimated that in the world there were 4.7 billion mobile phone subscribers and 3.174 million Internet users. Regarding GDP growth, productivity, and employment, between 2005 and 2010 it represented between 0.5 and $5.4 \%$ of GDP in developing countries; and between 1.7 and $6.3 \%$ in more advanced economies. Regarding mobile telephony and the use of smartphones to use services and applications, it is expected that $60 \%$ of the world's population will use this device as the main means of communication by 2020 (ECLAC, 2015).

Electronic commerce in 2014 represented $2 \%$ of world GDP, almost 1.3 trillion dollars, however, in the wine industry this business model is not what they are looking for in its entirety. The large wine-producing industry entered the online catalog sales market, however, after a few years they realized that consumers in this sector preferred to buy the product directly in establishments and only use the web pages to know information about the company, products, and prices. Most SME warehouses use their websites to improve the effectiveness of their online sales channel by providing information to customers on inventory levels, orders, shipping costs, and delivery time estimates (Neilson, Madill, \& Haines, 2010, p. 139).
The new markets and communication channels have favored the incursion to other countries, through the exchange of information on the products offered, thereby increasing exports and direct national sales, rather than online sales. The nature of internet marketing in this industry should be as a virtual community in which intensive relationships are built with its consumers for a better understanding of their needs and requirements, fundamental for the success of a winery (Strangelove, 1995, pp. 4144).

Tom Cochran (advisor to Barack Obama, president of the United States in the period 20092017), was the key figure of the democratic government by using technology and new applications such as Facebook and Google so that the president had a Promising digital income to many people. Tom in an interview for WineNews recommended to the wine industry, characterized by its traditional methods, using online technology to have contact with new consumers, as well as having sites and social platforms to advertise it (Wine News, 2020). In Italy and in many European cities, web marketing is particularly important since the technology in the distribution and product search systems are used by almost $50 \%$ of the online traffic in the search engine called Google.

\section{The financing of companies through technological innovation}

The financing of SMEs in the agro-industrial sector is determined in each country according to the production and demand of the product, giving priority to the activities of the primary sector. The financing options offered by government entities and financial institutions are subject to the availability of funds and project viability. The wine industry in the main producing countries is a fundamental part of the economic sector due to the habit of consumption and the number of exports of its products, which is why it enjoys state investors to maintain its competitiveness as in the case of the Tuscany Region in Italy, or the French government that has financing programs in case of environmental contingencies or economic crises that guarantee the payment of local taxes by companies and taxes on their exports. 
In Mexico, the Government of the Republic, through the Ministry of the Economy, has two main forms of financing: loan to lost funds and the national entrepreneurial fund. The loan to lost funds is a grant destined for operational projects or in their initial phase with the objective of promoting social welfare, innovation, and competitiveness; this financial support is exempt from the payment of commissions, interest or refund of the amount obtained (Salloum \& Vigier, 1997, p. 2-7). The National Entrepreneur Fund is a subsidy, and its objective is to "increase productivity in micro, small and medium-sized enterprises, mainly those located in priority sectors. Through actions that favor access to financing; development of human capital; strengthening of productive, technological and innovation capacities, as well as their insertion in value chains and supply chains" (Fondo Nacional Emprendedores, 2020).

However, there are other financing options for SMEs such as loans from family or friends, the sale of an asset or the so-called crowdfunding. Microfinance or crowdfunding is the practice of fundraising for a project or company financed by small amounts of money contributed by many people, this collection is generally done through a digital platform on the Internet (Agrawal, Catalini et al, 2015). Collective investment is carried out through a digital platform in which groups of people with similar interests create a network to get money and other resources. Based on the use of the Internet and social networks, a crowdfunding platform is "an Internet application that brings together project owners and their potential sponsors, in addition to facilitating the exchange of project participants according to commercial market models current" (Shneor \& Flåten, 2015, p. 21).

The concept of crowdfunding emerged in England in 1997, but until 2009 the Quickstarter platform promoted it, giving way to other important companies such as Verkami. This concept has specific economic, technological, social, or cultural strategies. The purposes for financing capital by this mean are development of prototypes or ideas, birth of companies or investment for their growth, political campaigns, debt financing, school projects, artistic movements, or donations with a cause.
In each one, the production process, the amount of financing, collection time and rewards for investors are explained. Investors or sponsors contribute a small amount of money to obtain a reward when the financial goal has been met. The return on investment is made through a product or a service, although some projects have other purposes such as long-term investment, loan and return of interest, donation for cause only or donation through a reward (Shneor, 2020 pp. 23-31).

According to information from the World Bank for the year 2012, campaigns through crowdfunding business models and their digital platforms raised approximately 2.7 billion dollars, estimating that global volumes could reach 96 billion dollars by 2025 (infoDev, 2013). A successful business model for this form of financing is the Italian company Winelivery founded in 2016, who through crowdfunding created an online sales website (ecommerce) and home delivery of alcoholic beverages. This company has raised from its foundation until 2019 the amount of 1 million 850 thousand euros (Winelivery, 2020).

In the wine industry, Argentine companies in southern Mendoza are those that have currently opted for collective financing crowdfunding to develop their own vineyard, as well as Spanish companies that have carried out a campaign to create a collaborative wine, such as the Lonxe de Galicia company, Spain that also includes in its campaign products from collaborators in the area to create a local consumer network. This collaborative works is essential because of the intangible cultural heritage of traditions, skills, knowledge, and community improvement (Guiné, et al., 2021, p. 18). It should be noted that this financing is recommended in medium and small companies due to its marginal productivity.

\section{Theories of Internationalization}

The concept of business internationalization is a term that has been widely discussed over several decades since it is confused with the term of globalization. In this way, companies for a long time were classified by multinational or global, clearly counting on some differences. 
On the one hand, multinational companies operated in several countries or continents, their products being almost the same and where strategic decisions were made at the headquarters of the country where they reside. On the other hand, global companies were established around the world, the products could be different depending on the market and sometimes even with a different brand; where decisions were made from headquarters in different parts of the world (Araya, 2009, pp. 1822).

Today, international organizations have developed capabilities that allow them to compete in various markets, allowing them to improve the value-added chain. Whether it is to expand your market, diversify your products or improve your income, internationalization is now a necessity for the survival of the company. The strategies that must be followed to achieve this require several measures that must be evaluated by trained personnel in terms of strategic competence with experience in the business field and knowledge of the market to which they are going. The company must be aware of the needs that it will have to cover, the capacity of the company for the new production and the environment in which it will be established for its survival. In this sense, there are three ways to enter international markets: export, grant licenses or make your own investments directly in the country where you want to participate.

The Uppsala model defines four stages through which a company must go to enter a foreign market: sporadic or non-regular export activities, exports through independent representatives, establishment of a commercial branch in the foreign country and establishment of productive units in the foreign country. It also envisages a progressive international commitment of companies and market knowledge; as such knowledge increases, the level of resources committed to international activity, experience, and static and dynamic aspects of internationalization variables is increased (Ellis, 2000, cited in Trujillo et al., 2006, p. 14).
Jordi Canals model for internationalization is based on the idea that the internationalization of the company depends on the current or future globalization of the corresponding sector; as well as economic, market and business forces. According to Canals (1994), companies by the level of intensity in their internationalization process are classified into four: exporter, multinational, global, and transnational. Depending on the concentration of the activities you want to do; if it is as a finished product, as a supplier or value chain, as well as the degree of adaptation to local needs and the way to disseminate learning in the organization. The success, duration and expansion of a company depends on an adequate design of an internationalization plan; from short and longterm objectives to factors such as the similarity of international markets with the global market. Geographical proximity, the existence of effective and cheap distribution channels, the potential market size, competition in the same sector and the rivalry of existing companies also require a rigorous control mechanism that allows the evaluation of results. It is worth mentioning that the lack of knowledge and resources are among the main obstacles to internationalization since today's consumer demands greater variety and speed in service. This author classifies companies into four groups: the exporter, from the country of origin; the multinational, which is characterized by the decentralization of all activities, reproducing parent companies in each of the foreign subsidiaries; the global one, with a combination of activities and a capacity to adapt to each country and market; and the transnational, which tries to combine economic efficiency with the ability to adapt to local markets. All of these follow a sequential process, which increases the level of commitment, which includes the initiation, development, and consolidation stages (Canals, 1994, cited in Trujillo et al., 2006, p. 18).

The Way Station model is directly derived from experience and indicates the way forward in the internationalization process, which will be successful if at least the first five stages of the following are met: motivation and strategic planning, market research, selection of markets, selection of the mode of entry, planning of problems and contingencies, post-entry strategy and linkage of resources and finally, acquired competitive advantage and total corporate result (Yip \& Monti, 1998). 
The model advocated by Johanson, and Mattson (1988) considers business networks to be those that companies maintain with their clients, distributors, competitors, and government. When companies are internationalized in a network approach, relationships are formed with partners in new countries, commitment to existing networks is increased and the positions of networks in different countries are integrated, which allows the company to maintain relationships to have access to resources and markets. This also favors small and medium-sized companies without experience in the international market. The authors classify companies in four, according to their degree of internationalization of the network: initiator, laggard, lonely and international along with other companies (Johanson \& Mattson, 1988, pp. 287-314).

Companies must be clear about the reasons to seek internationalization mainly: diversify products and markets, gain competitiveness, sell higher volumes, take advantage of preferential agreements, and achieve higher profits.

According to the Proexport Colombia Trust, here are some options that can help the company identify the factors that motivate its decision (Lozano, 2010, p. 177):

Diversify products and markets to face international competition and the situation of the national economy.

Gain competitiveness through the acquisition of technology and managerial capacity obtained in the market.

- Make strategic alliances with foreign companies to reduce costs, improve efficiency and diversify products.

Reduce the risk of belonging to a single market.

- $\quad$ Sell larger volumes to use the productive capacity of the company and achieve economies of scale.

Exploit comparative advantages and the opportunities of expanded markets through preferential agreements.
- $\quad$ Need to get involved in the world market due to the globalization of the economy.

- $\quad$ Seek greater profitability in international markets and ensure the long-term existence of the company.

Economic integration is a model where the member countries establish trade agreements to eliminate some barriers in the exchange of products or services. Bela Balassa (1961) contemplates four stages in economic integration between two or more countries:

1. The free trade zone, a territorial area in which there are no national customs, that is, there is free flow of products, and no tariffs are paid (independence with products from third countries is maintained).

2. The customs union contemplates the formation of a single entity in the field of international trade, where member states do not pay tariffs, thanks to a common foreign trade policy.

3. The common market, a customs union with free mobility of productive factors, goods, and services. They have a common commercial policy and legislation in common.

4. The economic union that consists of the adoption of a single currency and monetary policy (Malamud, 2011, p. 221).

In processes linked to globalization, regional integration is interpreted as a protectionist maneuver by the States that is known as regionalism. In this formalized process, the national states are related or merged to guarantee their interests and objectives by themselves. "They voluntarily mix, confuse and merge with their neighbors, in such a way that they lose certain factual attributes of sovereignty, while at the same time they acquire new techniques to jointly resolve their conflicts" (Haas, 1971, p.6). 
Competitiveness and technological innovation are fundamental elements to strengthen the internationalization of the Mexican Wine Industry, since it allows it to have the necessary conditions to adapt to the demands of the current market, both in the execution capacity to expand the company, as the means of diffusion to commercialize and transport the product or service. Competitiveness in the administration of resources, the design of initiatives and the skills to adapt to a multicultural scenario facilitate the internationalization of the company and the commercial exchange between countries.

Capital investment efforts in innovation in production and improvement of the quality of wine products, as well as management possibilities in the supply channel will allow entrepreneurs to implement collaborative marketing strategies that will foster increased demand and reducing market risk (Menna \& Walsh, 2019, p. 200).

The development of information technologies and digital media has had a significant impact on the way people communicate and the ways of doing business. These platforms have facilitated multidirectional communication with the company's value chain, giving it a competitive advantage. With this, the wine cellars not only seek to publicize their product and attract customers, but they also aim to promote collaboration networks in the community and wine production areas by adopting wine tourism strategies that can give them a dominant market share at national and international level.

\section{Conclusion}

After reviewing some of the theories that favor the internationalization of the company, we have concluded that competitiveness in the wine industry allows the strengthening of productive capacities for the integral development of the economic systems involved in the development of the company and the wine sector. At national and international level. Likewise, the incorporation of digital technologies in daily activities has contributed to economic growth and social development, in the same way that it has created opportunities for the exchange and collaboration of services with greater efficiency and speed.
The Internet and digital media, while increasing the consumer society, also contribute to the progress of countries with more technological capabilities in terms of their participation in the Gross Domestic Product. This development of information and communication technologies gives companies an added value that allows them to have the conditions to compete in current and future markets.

Technology in the wine industry is critical to internationalization as it allows it to innovate processes by improving quality, increasing its productive capacity, and reducing costs that gives it access to markets with regulatory price systems and international regulations. Likewise, technological innovation allows improvements in the information systems of suppliers, processes, clients, as well as participation in competitions of the sector in terms of recognitions and awards. In this framework, the International Organization of Vine and Wine (OIV) in 2020, launched a call to develop web platforms to adapt to the current conditions of online marketing of wine products around the world and provide new communication channels.

Communication within the wine industry is critical to internationalization as organizational leadership has become relevant for globalization of markets, strong competition and reduced product life cycles. Good communication allows the company to reach the levels of competitiveness necessary for the dynamic development of communication, information, and transport technologies.

Considering the current situation in the world, two recommendations are offered. The first is to make a diagnosis of the organization in which the management determines the needs of the company, the production capacity to adapt to a new business model and the financing of research and development expenses. The second is to make the determination to choose a funding model to raise funds both to invest in knowledge and to start or improve a business project. 


\section{References}

Agrawal, A., C. Catalini, \& A. Goldfarb. (2015). Crowdfunding: Geography, Social Networks, and the Timing of Investment Decisions. Journal of Economics \& Management Strategy 24 (2), pp. 253-274.

Araya, A. (2009). El proceso de internacionalización de las empresas. TEC Empresarial, 3, pp. 18-25.

BAI, Agencia de innovación (s.f) Modelos de vigilancia tecnológica e inteligencia competitiva. El entorno de la inteligencia Competitiva, Bilbao, p. 14, D.L. BI-611-07.

Barney, J. (1991). Firm resources and sustained competitive advantage. Journal of management, 17, pp. 99-120.

Brecher, A., \& Choudhri, E. (1993). Some Empirical support for the Heckscher Ohlin Model of Production. The Canadian Journal of Economics, 26 (2), pp. 272-285.

Brenes, G., \& León, F. (2008). Las born Global: empresas de acelerada internacionalización. TEC Empresarial, 2, pp. 9-19.

Canals, J. (1994). La internacionalización de la empresa. Cómo evaluar la penetración en mercados exteriores. España: Mc Graw Hill.

Casa Madero. (2020). Consulted in (15-07 2020) http://madero.com/historia/

Cassiman, B., \& Sieber, S. (2001). El impacto de internet sobre la estructura de los mercados. IESE Business School, III (339), pp. 12-24.

Appleyard, D.R. \& Field, A. J. (2014). International Economics, 8 ed., New York, McGraw-Hill, pp. 127-154.

Collís, D. J. (2019). The Value Potential of New Business Models. Harvard Business School. Working papael 20-028, pp. 1-11.

Consejo Mexicano Vitivícola. (2019). Consulted in (05-04-2019) https://uvayvino.org.mx/

Crevoisier, O. (Février de 2001). L'approche para les milieux innovateurs:état des lieux et perspectives. Revue d'économie régionale \& urbaine (1), pp. 153-165.

ISSN: 2444-5037

ECORFAN® All rights reserved.
Ellis, P. (2000). Social Ties and Foreign Market Entry. Journal of International Business Studies, 3 ed., Vol. 31.

Fernández, J. (2013). La evolución reciente del sector vitivinícola internacinal. Geographos, 4(39), p. 22.

Fernández, J., \& Subirá, E. (2006). El teorema de Heckscher-Ohlin a la luz de las tablas inputoutput de la Unión Europea. Universidad de Barcelona, p. 85.

Fondo Nacional Emprendedores. (2020). Consulted in (25-09-2020) https://www.sistemaemprendedor.gob.mx/

Forbes México. (2019). Consulted in (22-052019) https://www.forbes.com.mx/forbeslife/vino-mexicano-es-revelacion-mundial-delconcours-mondial-de-bruxelles/

Gee. S. (1981). Tecnology Transfer, Innovation and international competitivenes. New York: John Wiley \& Sons

Godet, M. (1993). De la anticipación a la acción. Manual de prospectiva y estrategia. España: MARCOMBO, pp. 329-355.

Grant, R. (1991). The resource-based theory of competitive advantage, implications for strategy. 33(3), pp. 114-135.

Guiné, R. P., Florença, S. G. Barroca, M. J., \& Anjos, O. (2021). The duality of innovation and food development versus purely traditional foods. Trends in Food Science \& Technology, pp. 16-24.

Haas, E. B. (1971). The Study of Regional Integration: Reflections on the Joy and Anguish of Pretheorizing, en Neon N. Lindberg y Stuart A. Scheingold, eds., Regional Integration: Theory and Research, Cambridge, Mass., Harvard University Press, pp. 3-44.

Hategan, A. (2012). Litterature Review of the Evolution of Competitiveness concept. The annals of the University of Oradea, pp. 41-46.

Hernández, J., Gallarzo, M., \& Espinoza, J. (2011). Desarrollo Organizacional. Enfoque lationoamericano (Primera ed.). México: PEARSON EDUCACION.

MOLINA-MARTÍNEZ, Rubén \& BALTAZAR-RAMOS, Vianey. Competitiveness and technological innovation, fundamental theoretical elements for the internationalization of the Mexican Wine Industry. Journal of Microfinance Planning and Control. 2021 
Hill, C. (2015). Teoría del comercio internacional Negocios Internacionales (Décima ed.). Washington, Estados Unidos: Mc Grawhill, pp. 157-181.

infoDev. (2013). Crowdfunding's Potential for the Developing World. The World Bank. Washington: Finance and Private Sector Development Department. Consulted in (20-072020).

Johanson, J., \& Mattson, L.G. (1988). Internationalization of the firm A model of knowledge development and increasing foreign market commitments, Journal of International Business Studies, 8 (1), pp. 23-32.

Kahaner, L. (1997). Competitive intelligence: how to gather, analyza, and use information to move your business to the top. New York: TOUCHSTONE, pp. 20-35.

Krugman, P. (1994). Competitiveness: A Dangerous Obsession. Foreing Affairs, 73 (2), pp. 28-44.

Leamer, E. (1980). The Leontief Paradox, reconsidered. The journal of political economy, pp. 495-503.

Lozano, F. D. La asociatividad como modelo de gestión para promover las exportaciones en las pequeñas y medianas empresas en Colombia. Revista-Bogotá (Colombia), 5 (2), pp. 161-191.

Malamud, A. (2011). Conceptos, teorias y debates sobre la integración regional. Norteamerica, 6 (2), July-September 2011, pp. 219-249.

Martinet y Marti, B. (1995). L'intelligence economique. Les yeux et le oreilles de 1'entreprise. Les Editions d'Organisation, 43 (2), Paris, Avril-Juin 1997, pp. 106-107.

Menna, A., \& Walsh, P. R. (2019). Assessing environments of commercialization of innovation for SMEs in the global wine industry: A market dynamics approach. Wine Economics and Policy 8, Canadá, pp. 191-202. Consulted in (12-10-2020).

Montoya, O. (2004). Shumpeter, innovación y determinismo tecnológico. Scientia et Technica 10 (25), Colombia, pp. 209-213.
Morales, M., \& Pech, J. (2000). Competitividad y estrategia: el enfoque de las competencias esenciales y el enfoque basado en recursos. Contaduría y Administración, p. 49.

Neilson, L., Madill, J., \& Haines, G. (2010). The development of e-business in wine industry SMEs: an international perspective. Int. $J$. Electronic Business, 8(2), pp. 126-147.

Oviatt, B.M., \& McDougall, P.P. (1994). Toward a theory of international new ventures. Journal of International Business Studies, first quarter, 25, pp. 45-64.

Pavlou, P. A., \& Sawy, O. A., (2011). Undestanding the elusive black box of Dynamic capabilities. Decision Sciences 42 (1), pp. 239273.

Peña, A. R. (2006). Las disparidades económicas intrarregionales en Andalucia [Tesis doctoral, Universidad de Cádiz, España] páginas 580.

Pitelis, C. N., \& Teece, D. J. (2009). The (new) nature and essence of the firma. European Management Review (6), pp. 5-15.

Plá, J., \& León, F. (2004). Dirección de Empresas Internacionales. Madrid, España: Pearson Educación, pp. 1-384.

Plá, J., \& Escribá, A. (2006). Accelerated internationalization: Evidence from a late investor economy. International Marketing Review, 23(2), pp. 255-278.

Porter, M. (1985). Estrategia competitiva: Técnicas para el análisis de los sectores industriales y de la competencia. México: Continental, pp. 51-63.

Porter, M. (1990). The competitive advantage of nations. Harvard Business Review, 68 (2), pp. 73-93.

Porter, M. (1999). La ventaja competitiva de las naciones. Bilbao: Deusto.

Porter, M. (2010). Ventaja competitiva (novena ed.). México: Grupo editorial patria.

Rivera, J., Arellano, R., \& Molero, V. (2013). Conducta del consumidor: estrategias $y$ políticas aplicadas a las variables (Tercera ed.). Madrid: Esic.

MOLINA-MARTÍNEZ, Rubén \& BALTAZAR-RAMOS, Vianey. Competitiveness and technological innovation, fundamental theoretical elements for the internationalization of the Mexican Wine Industry. Journal of Microfinance Planning and Control. 2021 
Sazali, A.W. \& Raduan, C. R. (2011). The Handbook of Inter Firm Technology Transfer: An Integrated Knowledge-Based View and Organizational Learning Perspective. Germany: LAP LAMBERT Academic Publishing.

Salloum, C., \& Vigier, H. (1997). Los problemas de financiamiento de la pequeña y mediana empresa: Relación Bancos-PyMEs, pp. 2-7.

Sepúlveda, V. E., Temas económicos y sociales de actualidad en México. Charlas en mangas de camisa. México: Museo Interactivo de Economía, 2010, p. 287.

Schumpeter, J.A. (1934). The Theory of economic development. The Theory of economic development: an inquiry into profits, capital, credit, interes and the business cycle, Harvard Economic Studies, Vol. 46, Harvard College, Cambridge, MA.

Schumpeter, J.A. (1939) Business Cycles: A Theoretical, Historical, and Statistical Analysis of the Capitalist Process. McGraw-Hill, New York.

Schumpeter, J.A. (1942) Capitalism, Socialism, and Democracy. Third Edition. New York: Harper, p. 83

Shneor, R. (2020). Crowdfunding Models, Strategies, and Choices Between Them. Advances in Crowdfunding, pp. 21-42. Consulted in (12-08-2020) https://doi.org/10.1007/978-3-030-46309-0_2

Shneor, R., \& Flåten, B. (2015). Opportunities for Entrepreneurial Development and Growth through Online Communities,Collaboration, and Value Creating and Co-Creating Activities. Kaufmann H.R., Shams S.M.R. (eds) Etrepreneurial Challenges in the 21st Century, pp. 178-199. https://doi.org/10.1057/9781137479761_11

Strangelove, M. (1995). The walls come down: net age advertisisng empowers consumers, Internet World, pp. 41-44.

Teece, D. (2007). Explicating dynamic capabilities: the nature and microfoundatins of (sustainable) enterprise performance. Strategic management jornal, 28, pp. 1319-1350.
Trujillo, M.A., Rodríguez, D.F., Guzmán, A., \& Becerra, G. (2006). Perspectivas teóricas sobre la internacionalización de empresas. Ed. Universidad del Rosario, 30, pp. 1-78.

Wernerfelt, B. (1984). A resource-based view of the firm. Strategic Management Jorunal. 5 (2), (April-June, 1984), pp. 171-180.

Winelivery. (2020). Consulted in (10-07-2020). https://www.winelivery.com/it

Wine News. (2020). Consulted in (29-01-2020) https://winenews.it/it/la-tecnologia-strumentofondamentale-per-la-comunicazione-del-vinoparla-tom-cochran_407529/ 